\title{
PENGARUH NILAI TUKAR RUPIAH, INFLASI DAN PERTUMBUHAN EKONOMI TERHADAP UTANG LUAR NEGERI INDONESIA TAHUN 2000-2017
}

\section{Sofian Ibrahim, Wahyu Hidayat, Ida Nuraini}

Program Studi Ekonomi Pembangunan, Fakultas Ekonomi dan Bisnis, Universitas Muhammadiyah Malang, Jl.Raya Tlogomas No.246 Malang, Indonesia

* Corresponding author: Ibrahim.sofian94@gmail.com

\begin{tabular}{|c|c|}
\hline Artikel Info & \multirow{12}{*}{$\begin{array}{l}\text { Abstract } \\
\text { The purpose of this study was to analyze how the effect of } \\
\text { exchange rate of rupiah, inflation and Economic Growth on } \\
\text { Foreign debt in Indonesia in 2000-2017. The instrument } \\
\text { Analysis used multiple linear regression method with OLS } \\
\text { (ordinary least squares) method by using time series data. The } \\
\text { method test using the classical assumption test and statistical } \\
\text { test.From the analysis results obtained that the effect of } \\
\text { exchange rate of rupiah is has positively effect and inflation } \\
\text { have a negative effect while Economic Growth have a negative } \\
\text { effect. Simultaneously of all these variables have a significant } \\
\text { effect on Foreign debt in Indonesia. The conclusion of this } \\
\text { reserch explains that all of variables, exchange rate of rupiah } \\
\text { and Economic Growth variables have a significant postive } \\
\text { effect on Foreign debt, and the variable that negatively effect on } \\
\text { Foreign debt in Indonesia is inflation variable. }\end{array}$} \\
\hline Article history: & \\
\hline Received 18 April 2019 & \\
\hline Revised 25 April 2019 & \\
\hline Accepted 17 May 2019 & \\
\hline Available online 20 & \\
\hline 2019 & \\
\hline Keyword: $\quad$ Foreign $\quad$ debt; & \\
\hline exchange rate of rupiah; & \\
\hline inflation; Economic Growth & \\
\hline JEL Classification & \\
\hline E31; F31; F43 & \\
\hline
\end{tabular}

\section{PENDAHULUAN}

Pembangunan ekonomi merupakan prasyaratan mutlak bagi negaranegara berkembang atau sering disebut negeri dunia ketiga termasuk Indonesia, untuk mengejar ketertinggalannya dari negara maju banyak hal perlu dilakukan. Akan tetapi agak terkendala kurangnya sumber daya modal yang sebagai salah satu pemicu pembangangnan (Atmaja, 2015). Agar memenuhi kekurangan sumber daya modal ini, maka negara pemeritah bersangkutan yang berusaha untuk mendatangkan bantuan sumberdaya modal dari luar negeri melalui ekspor, investasi asing (PMA) dan bantuan luar negeri (peminjaman utang) yang sering digunakan oleh pemerintah. Agar menutupi kekurangan pemerintah dalam memperlancar proses program pembangunan nasional, maka salah satu sumber pendanaan adalah bersumber dari utang luar negeri yang digunakan. Bagi negara-negara berkembang menjadikan utang sebagai alternatif biaya pembangunan tak terkecuali Indonesia (Ramadhani, 2014). Utang luar negeri sering kali muncul ketika negara-negara berkembang memerlukan dana yang cukup besar untuk membiayai pengeluaran pembangunan.

Pembangunan yang terus menekankan pada proyek-proyek mega infrastruktur dan yang berteknologi tinggi dan membutukan dana yang cukup besar, dalam perakteknya justru dibiayai dengan utang luar negeri, telah membawa Indonesia pada model pembiayaan sepenuhnya pada utang luar negeri, sementara disisi lain, sektor - sektor yang diharapkan sebagai sumber penerimaan negara belum mampu menutupi kebutuhan akan dana yang semakin besar dalam membiayai pembangunan. 
Kebijakan-kebijakan yang telah diambil oleh pemerintah hingga saat ini dalam rangka mengurangi utang luar negeri, namun dalam kenyataannya tidak efektif dan masih sulit untuk dikendalikan. Penyebab dari kurangnya efektifnya dalam usaha pengendalian utang luar negeri ini disebabkan oleh banyak faktor yang ditimbulkan dari dalam negeri dan juga berasal dari luar negeri yang sulit diprediksi, termaksud defisit anggara yang paling besar. Disisi lain termaksud juga banyak faktor-faktor itu yang mampu mempengaruhi utang luar negeri tiap tahunnya. Seperti faktor pergerakan nilai tukar rupiah terhadap dollar yang sulit diperkuat, inflasi yang bisa saja tidak stabil karena biaya impor yang selalu naik dan terakhir pembangunan yang berkelanjutan untuk meningkatkan pertumbuhan ekonomi yang signifikan membutukan dana yang cukup untuk menyelsaikan persoalan ekonomi.

Suatu negara melakukan peminjaman ke luar negeri, jika ada gejolak nilai tukar setiap tahunnya maka negara tersebut akan mengalami masalah. Persoalan ini disebabkan karena nilai suatu pinjaman dihitung dengan salah satu valuta asing biasanya dengan dollar Amerika, sedangkan pada pelunasan pinjaman cicilan pokok dan bunga dihitung dengan peminjam mata uang negara tersebut. Misalnya bila nilai tukar rupiah terjadi apresiasi terhadap mata uang dollar AS, maka akan selalu dikuti dengan pengurangan pinjaman kurs nilai mata uang tersebut begitupun sebaliknya bila nilai tukar rupiah depresiasi terhadap mata uang dollar AS, maka akan selalu diikuti dengan penambahan pinjaman kurs nilai mata uang tersebut.

Perubahan pengeluaran karena adanya inflasi. Pada awal tahun penyusunan anggaran belanja negara, didasarkan dan ditetapkan menurut standar harga. Dalam perjalanan tahun anggaran harga standar itu sendiri, ketepatannya tidak dapat dijamin. Artinya, selama tahun anggaran standar berjalan harga itu dapat menurun tapi jarang sedangkan peningkatan itu terus terjadi. Apabila terjadi inflasi, dengan adanya kenaikan harga-harga itu berarti biaya program pembangunan ikut akan meningkat, sehingga ketika ketidakcukupan dana dalam negeri untuk mempercepat pembangunan perlu adanya penyelsaian salah satunya melalui peminjaman utang ke luar negeri (Puspitaningrum, 2018).

Mempercepat pembangunan untuk percepatan laju pertumbuhan ekonomi diperlukan investasi dan dana cukup besar. Jika dana yang tidak mencukupi dalam negeri, sebagai pilihan salah satu alternatifnya dengan meminjam keluar negeri akhirnya kebutuhan dana tadi menjadi persyaratan untuk pembangunan ekonomi seperti negara Indonesia. Jika kebutuhan itu terus bergantung akan berdampak pada peminjaman utang yang terus bertambah, tetapi ketika pertumbuhan itu naik akan diikuti pendapatan nasional maka akan mengurangi beban utang luar negeri. Sudah seharusnya negara wajib bertanggung jawab dalam menyelsaikan persoalan ekonomi yang diamanahkan dalam konstitusi.

Penelitian dilakukan oleh Tafonao (2016) yang menggunakan metode analisis regresi linear Ordinary Least Square (OLS) dalam penelitian ini. Hasil diperoleh menunjukan bahwa suku bunga dalam negeri, pertumbuhan ekonomi tidak berpengaruh signifikan terhadap total utang luar negeri pemerintah sedangkan nilai tukar berpangaruh positif signifikan terhadap total 
utang luar negeri pemerintah. Menunjukan hasil bahwa variabel yang paling besar kontribusinya dalam menjelaskan faktor - faktor yang mempengaruhi utang luar negeri adalah variabel suku Bunga Indonesia.

Sedangkan penelitian Ristuningsi (2016) yang menggunakan alat analisis Vector Eror Correction Model. Dengan tujuan untuk mengetahui keterkaitan hubungan antara nilai kurs, tingkat impor, tingkat inflasi dan tingkat ekspor terhadap total utang luar negeri Indonesia. Diperoleh hasil menunjukan bahwa kurs memilki hubungan keterkaitan dalam jangka pendek secara signifikan dengan utang luar negeri. Ekspor, impor dan inflasi memiliki keterkaitan dalam jangka panjang secara signifikan dengan utang luar negeri. Tetapi dalam jangka pendeknya menujukan keterkaitan yang kurang signifikan.

Uraian penelitian terdahulu dapat diketahui persamaan dan perbedaan bahasan antara penelitian terdahulu dengan topik peniliti. persamaan dari tiga penelitian terdahulu membahas tentang faktor-faktor yang terkait tentang utang luar negeri. Perbedaan antara penelitian terdahulu dengan topik peniliti yaitu terletak pada variabel independent. Penelitian-penelitian terdahulu diantarnya terdapat relevansi terhadap 3 variabel independent yaitu nilai kurs, inflasi, pertumbuhan ekonomi terhadap variabel independent yaitu utang luar negeri.

Teori Kuncoro (2009:53) menyatakan bahwa"setelah runtuhnya sitem Bretton Woods dan berkembangnya sistem kurs mengambang, bagi negara berkembang seperti Negara Indonesia, peranan kurs valas menjadi sangat penting, terutama terhadap mata uang keras (hard currencies) sepert dollar AS dan Yen jepang". Kurs valas sangat penting bagi Negara yang sedang melakukan pembangunan ekonomi, karena kurs valas akan berhubungan langsung dengan sektor-sektor perdagangan luar negeri, investasi, dan juga dengan utang luar negeri yang merupakan sumber dana pembangunan. Oleh karenanya kestabilan dan keterjangkauan kurs mutlak diperlukan. Fluktuasi kurs ini yang menyebabkan beban utang luar negeri yang merupakan sebagian dana untuk pembangunan menjadi semakin besar. (Ristuningsih, 2016).

Teori imported inflation dapat digunakan untuk menganalisa hubungan tingkat inflasi terhadap utang luar negeri. Dimana saat Indonesia mengalami inflasi, maka nilai tukar rupiah terhadap dollar akan lemah. Indonesia masih tergantung produk dari luar baik bahan baku atau bahan setengah jadi disektor barang dan jasa. Sehingga saat terjadi inflasi Indonesia, pemerintah membutuhkan dana yang lebih untuk memenuhi kebutuhan dalam negeri tersebut dan dibutuhkanlah utang luar negeri. inflasi harus tetap terjaga walaupun tidak secara langsung tidak dapat mengurangi utang luar negeri. (Ristuningsih, 2016).

Di Negara berkembang pembangunan ekonomi menjadi sebuah kewajiban untuk mempercepat pertumbuhan ekonomi dan sudah barang pasti meningkatkan taraf hidup masyarakat. Keharusan membangun merupakan suatu tuntunan agar pertumbuhan ekonomi yang lebih cepat. Dalam upaya mencapai laju pertumbuhan ekonomi, maka yang dibutuhkan adalah pendapatan/modal yang cukup demi terlaksananya pembangunan. Hal ini Indonesia selalu dihadapkan oleh beberapa kendala diantaranya kurangnya modal. Untuk mencukupi kekurangan modal, Indonesia mendatangkan 
bantuan dana dari luar negeri melalui utang luar negeri. Kenaikan utang luar negeri yang terus meningkat mencerminkan bahwa perekonomian Indonesia belum sepenuhnya bisa dibiayai oleh tabungan nasional (Astanti, 2015).

Adapun permasalahan yang terjadi peneliti akan membahas permasalahan yang ada dalam variabel mempengaruhi utang luar negeri. Peniliti ingin memastikan bahwa variabel yang berpengaruh terhadap utang luar negeri dan dalam penulis mengambil judul "pengaruh nilai tukar rupiah, inflasi dan pertumbuhan ekonomi terhadap utang luar negeri di Indonesia".

Penelitan ini berfokus pada tujuan penilitian yang mana tujuan tersebut yaitu untuk untuk menganalisis pengaruh nilai tukar rupiah, inflasi dan pertumbuhan ekonomi terhadap utang luar negeri di Indonesia tahun 20002017. Penilitian ini juga didasarkan terhadap penilitian-penilitian terdahulu atau menyempurnakan Hasil dari penelitian terdahulu sehingga diperoleh hasil yang lebih baik

\section{METODE PENELITIAN}

Obyek penlitian ini lakukan di Indonesia, penelitian yang dipilih oleh peneliti nilai tukar rupiah, inflasi dan pertumbuhan ekonomi terhadap utang luar negeri pada tahun 2000 hingga tahun 2017 dalam tahunan yang menggunakan data terbaru Penilitian ini menggunakan jenis penilitian deskriptif dan jenis data kuantitatif yang menggunakan suatu skala numerik atau angka kemudian di analisa dengan uji hipotesis yang di berikan kalimat keterangan untuk mendeskripsikan data kuantitatif. Data yang digunakan dalam penelitian ini menggunakan data dalam runtut waktu (times series) yaitu data yang secara kronologis disusun menurut waktu pada suatu variabel tertentu (Kuncoro, 2013:145). Data yang digunakan dalam penelitian ini menggunakan data sekunder yaitu data yang dikumpulkan oleh lembaga pengumpul data dan diterbitkan kepada masyarakat pengguna data (Kuncoro, 2013:148). Lembaga yang digunakan untuk mendapatkan sumber data dalam penelitian ini adalah Bank Indonesia (BI) dan Badan Pusat Statistik (BPS) dan Kementerian Keuangan.

Data yang digunakan dalam penilitian ini diperoleh dengan menggunakan teknik dokumentasi yaitu metode atau proses untuk memperoleh data dengan cara mengumpulkan, mempelajari dan mengolah data dari sumber-sumber instansi terkait, misalnya dari hasil penelitian terdahulu, skripsi/thesis, jurnal, buku pustaka, dan dokumen - dokumen yang terkait dengan penelitian ini. Sumber data di peroleh dari badan pusat statistik (BPS), Bank Indonesia dan kementrian keuangan yang di publikasikan di www.bi.go.id, www.bps.go.id dan www.kemenkeu.go.id

Penilitian menggunakan variabel opersiaonal yaitu Nilai tukar rupiah (IDR) dalam bentuk satuan rupiah terhadap dollar Amerika, Inflasi (I) dan Pertumbuhan ekonomi (G) dalam bentuk satuan persen (\%) sebagai variabel independent. Utang luar negeri sebagai variabel dependent dalam bentuk satuan mata uang dollar Amerika (USD).

Penelitian ini menggunakan analisis regresi linear berganda, Sedangkan metode yang digunakan merupakan metode Ordinary Least Squere (OLS) yang menggunakan data tahun 2000 - 2017. Variabel nilai tukar rupiah, inflasi dan 
pertumbuhan ekonomi yang mempengaruhi utang luar negeri tersebut dapat digambarkan dengan fungsi sebagai berikut :

$$
U L N=\lambda+\beta 1 I D R+\beta 2 I+\beta 3 G+\mu
$$

Dimana:

$$
\begin{array}{ll}
\lambda & =\text { Intercept } \\
\mathrm{ULN} & =\text { Utang luar negeri (Y) } \\
\mathrm{IDR} & =\text { Nilai tukar rupiah (X1) } \\
\mathrm{I} & =\text { Inflasi (X2) } \\
\mathrm{G} & =\text { Pertumbuhan Ekonomi (X3) } \\
\beta 0, \beta 1, \beta 2, \beta 3 & =\text { Koefisien regresi } \\
\mu & =\text { Variabel gangguan (Error term) }
\end{array}
$$

Teknik analisis yang digunakan yaitu menggunakan teknik analisis regresi linear berganda menggunakan analisis pendekatan time series dalam kurun waktu 18 tahun yaitu tahun 2000-2017, meliputi teknik analisis data dan uji statistik.

1. Uji normalitas berguna untuk menguji dalam model regresi data time series yang di kumpulkan apakah nilai residual berdistribusi normal atau tidak dengan membandingkan nilai Jarque-Bera (JB) dan Nilai Chi Square, tabel kriteria yang digunakan menerma $\mathrm{H} 0$ jika nilai Jarque-Bera $<$ nilai Chi Square maka data berdistribusi normal (Gujarati, 2012:125).

2. Uji autokorelasi yaitu sebuah analisis statistik yang dilakukan untuk mengetahui adakah korelasi didalam model prediksi dalam perubahan waktu. atau harus dilakukan korelasi antara anggota serangkaian observasi yang diurutkan menurut waktu seperti data time series.

3. Uji Multikolinieritas yaitu uji yang dilakukan untuk memastikan apakah di dalam sebuah model regresi ada interkorelasi atau koliniearitas antar variabel bebas. Tetapi salah satu asumsi regresi linear klasik adalah tidak adanya multikolinieritas sempurna (no perfect multicolinieritas).

4. Uji Heterokedastisitas yaitu uji semua pengamatan pada model regresi linear untuk menilai apakah ada ketidaksamaan varian dari residual. apabila tidak terpenuhi asumsi heterokedastisitas, maka model regresi dinyatakan tidak valid sebagai alat peramalan.

Adapun teknik analisis data time series adalah uji statistic antara lain :

1. Uji F atau F-test (over all test) Suatu pengujian yang dilakukan untuk membuktikan dalam analisis adanya koefisien regresi berpengaruh signifikan yang berarti dari variabel-variabel bebas secara keseluruhan terhadap variabel terikat. Untuk mengetahui signifikan tidaknya koefisien regresi secara serentak akan dilihat dan membandingkan antara F-hitung dengan F-tabel dengan rumus :

$$
F=\frac{\left(R^{2} / k\right)}{\left(1-R^{2}\right) /(n-k-1)}
$$

2. Uji $\mathrm{t}$ atau t-test (partial test) Uji signinifikan terhadap masing-masing koefisien regersi diperlukan untuk mengetahui signifikan tidaknya pengaruh dari variabel bebas terhadap variabel terikat secara partial. Atau mengetahui signifikan tidaknya koefisien regresi secara partial (Gujarati, 
2012:114). Dapat dilihat dan dibandingkan antara t-hitung dan t-tabel dengan rumus :

$$
t=\frac{\hat{\beta}_{j}-\beta_{j}}{\operatorname{se}\left(\hat{\beta}_{j}\right)}
$$

3. Koefisien Determinasi R2 (coefficient of determination) yaitu Koefesien korelasi majemuk yang mengukur tingkat varibel terikat $(\mathrm{Y})$ dengan semua variabel bebas yang menjelaskan secara bersama-sama, dan nilainya selalu positif. dan untuk menjelaskan seberapa besar variasi dari variabel terikat dapat diterapkan oleh variabel bebas. apabila $\mathrm{R} 2=0$, artinya variabel terikat tidak dapat diterapkan oleh variabel bebas sama sekali. Sementara apabila $\mathrm{R} 2=1$, artinya variasi dari variabel terikat dapat di terangkan $100 \%$ oleh variabel bebas.

\section{HASIL DAN PEMBAHASAN}

Estimasi regresi data linier berganda agar analisis model regresi bebas dari masalah-masalah asumsi klasik dan hasil OLS (Ordinari Least Squere), maka perlu dilakukan pengujian asumsi klasik antara lain Pengujian normalitas, multikolinieritas autokorelasi dan Heterokredastisitas. Uji normalitas yaitu nilai residual berdistribusi normal atau tidak dengan melihat nilai Jarque-Bera (JB) dan nilai probability. Kriteria yang digunakan menerima H0 jika nilai Jarque-Bera (JB) dan nilai probability $>$ dari $\alpha=0,05$, maka data berdistribusi normal. Diketahui hasil dari uji normalitas dengan menggunakan Eviews pada tabel 4.5 menunjukkan nilai Jarque-Bera sebesar 1,451125 dan nilai probability sebesar 0,484052 nilai tersebut lebih besar dari $\alpha=0,05$, maka dapat disimpulkan bahwa nilai residual dari model regresi data times series berdistribusi normal.

Pengujian autokorelasi bertujuan untuk mengetahui apakah ada korelasi antara anggota serangkaian data observasi yang diuraikan menurut waktu (times series) atau ruang (cross section). Dalam penelitian ini menggunakan uji auto korelasi Durbin-Watson dengan kriteria pengujian jika dU $<\mathrm{DW}<4$-dU atau nilai DW terletak diantara dU dengan 4-dU maka dapat dikatakan model persamaan regresi tidak mengandung masalah autokorelasi.

\section{Tabel 1. Hasil Pengujian Autokorelasi (sebelum)}

\begin{tabular}{ccccc}
\hline $\mathrm{dL}$ & $\mathrm{Du}$ & $\mathrm{DW}$ & $4-\mathrm{dU}$ & $4-\mathrm{dL}$ \\
\hline 0,9331 & 1,6961 & 0.9086 & 2,3039 & 3,0669
\end{tabular}

Sumber : Data diolah, 2018

Dari hasil pengujian autokorelasi diperoleh nilai DW sebesar 0,9086 dengan jumlah penelitian $(\mathrm{n})=18$, jumlah variabel bebas $(\mathrm{k})=3$, maka diperoleh nilai $\mathrm{dL}=0,9331$ dan $\mathrm{dU}=1,6961$, sehingga nilai 4-dU $=2,3039$ dan 4-dL $=3,0669$. Karena nilai Durbin-Watson (DW) sebesar 0,9086 terletak disebelah kiri dL dan dU, maka dapat disimpulkan bahwa model persamaan regresi terjadi masalah autokorelasi. Penanganan masalah autokorelasi dengan menggunakan metode Cochrane-Orcutt yang diasumsikan bila struktur 
autokorelasi tidak diketahui (Gudjarati, 2012). Yang berarti data ini sudah terbebas dari autokorelasi.

Tabel 2. Hasil Pengujian Autokorelasi (sesudah)

\begin{tabular}{ccccc}
\hline $\mathrm{dL}$ & $\mathrm{Du}$ & $\mathrm{DW}$ & $4-\mathrm{dU}$ & $4-\mathrm{dL}$ \\
\hline 0,9331 & 1,6961 & 2.1418 & 2,3039 & 3,0669
\end{tabular}

Sumber: Data diolah, 2018

Dari hasil pengujian autokorelasi yang sudah ditangani diperoleh nilai DW sebesar 2,1418 dengan jumlah penelitian $(n)=18$, jumlah variabel bebas $(\mathrm{k})=3$, maka diperoleh nilai $\mathrm{dL}=0,9331$ dan $\mathrm{dU}=1,6961$, sehingga nilai 4$\mathrm{dU}=2,3039$ dan 4-dL = 3,0669. Karena nilai Durbin-Watson (DW) sebesar 2,1418 sehingga terletak diantara 1,6961 dan 2,3039 maka dapat diartikan sudah tidak terjadi autokorelasi.

Pengujian multikolinieritas berarti adanya hubungan linier yang sempurna atau pasti antara beberapa bahkan semua variabel yang menjelaskan model regresi. Jika VIF (Variance Inflation Factor) lebih besar dari 10 (VIF>10) berarti terjadi multikolinieritas dalam regresi.

Tabel 3. Hasil Pengujian Multikolinieritas

\begin{tabular}{cccc}
\hline & Koefisien & Uncentered VIF & Centered VIF \\
\hline C & 1,464978 & 17158,39 & NA \\
X1 & 0,077597 & 14650,90 & 3,007275 \\
X2 & 0,001111 & 11,29414 & 1,904481 \\
X3 & 0,041699 & 280,6319 & 2,033612
\end{tabular}

Sumber: Data diolah, 2018

Dari output diatas dapat penulis jabarkan bahwa tidak terdapat variabel yang memiliki nilai centered VIF lebih dari 10 sehingga dapat disimpulkan bahwa tidak terjadi multikolinieritas dalam model regresi.

Heterokredastisitas merupakan kondisi dimana terdapat varians gangguan/error dari model regresi bersifat tidak konstan. Untuk mendeteksi adanya heterokredastisitas, penelitian ini menggunakan uji glejser yaitu, dengan melihat nilai probability chi-square. Kriteria yang digunakan adalah apabila nilai probability chi-square $>\alpha=0,05$ maka diputuskan untuk menerima $\mathrm{H} 0$, dan tidak terdapat masalah heterokredastisitas.

Tabel 4. Hasil Pengujian Heterokredastisitas

\begin{tabular}{llll} 
F-statistic & 3.139445 & Prob. F(3,11) & 0.0692 \\
Obs*R-squared & 6.919028 & Prob. Chi-Square(3) & 0.0745 \\
Scaled explained & & & \\
SS & 2.541432 & Prob. Chi-Square(3) & 0.4678 \\
\hline Sumber: Data diolah, 2018 & & &
\end{tabular}


Berdasarkan Tabel 4.9 diperoleh nilai probability chi-square $=0,0745$ dimana nilai tersebut lebih besar dari $\alpha=0,05$. Dengan demikian pada regresi data series ini diputuskan untuk menerima $\mathrm{HO}$ dan tidak terdapat masalah heterokredastisitas.

\section{Uji Hipotesis}

Uji F (Uji Serentak)

Hasil pengujian dengan menggunakan model regresi OLS (ordinary least squares) model menunjukkan nilai F-statistik sebesar 21,610 dan probabilitas (F-statistik) sebesar 0,000028. Dengan melihat perbandingan nilai probabilitas (F-statistik) yang lebih kecil dari nilai $\alpha=0,05$, maka dapat disimpulkan bahwa semua regressor (variabel independen dan variabel kontrol) memiliki pengaruh signifikan terhadap variabel dependen.

Uji t (Uji Parsial)

Hasil hipotesis nilai tukar rupiah (X1) t hitung nilainya adalah 6,66679 dimana nilai t tabel pada $\mathrm{df}=\mathrm{n}-\mathrm{k}=18-3=15$ dan $\alpha=0,05$ yaitu 1,75305 . Sedangkan dilihat dari probabilitasnya, nilai probabilitas $t$-statistik adalah sebesar 0,0001 dimana nilai tersebut lebih kecil dari pada derajad kesalahan $\alpha=0,05$. Berdasarkan hasil pengujian $t$ hitung, $t$ tabel dan probabilitas maka diputuskan untuk menolak $\mathrm{H} 0$, dan menerima $\mathrm{H} 1$, dan dapat dijelaskan bahwa variabel nilai tukar rupiah berpengaruh positif dan signifikan terhadap utang luar negeri.

Gambar 1. Kurva daerah penerimaan dan penolakan H0 untuk Variabel Nilai Tukar Rupiah (X1) pada Uji t Dua Arah

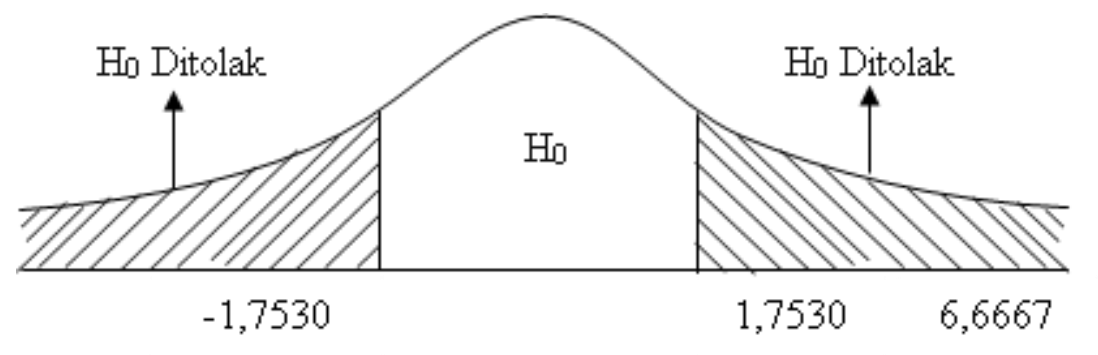

Hasil dari Hipotesis Inflasi (X2) t hitung nilainya adalah -3,741135, dimana nilai $\mathrm{t}$ tabel pada $\mathrm{df}=\mathrm{n}-\mathrm{k}=18-3=15$ dan $\alpha=0,05$ yaitu $-1,75305$. Sedangkan dilihat dari probabilitasnya, nilai probabilitas $\mathrm{t}$ - statistik adalah sebesar 0,0038 dimana nilai tersebut lebih kecil daripada derajad kesalahan $\alpha=$ 0,05 . Berdasarkan hasil pengujian $t$ hitung, $t$ tabel dan probabilitas maka diputuskan untuk menolak $\mathrm{H} 0$, dan menerima $\mathrm{H} 1$, dan dapat dijelaskan bahwa Inflasi berpengaruh negatif dan signifikan terhadap Utang Luar Negeri.

Gambar 2. Kurva daerah penerimaan dan penolakan HO untuk Variabel Inflasi (X2) pada Uji t Dua Arah 


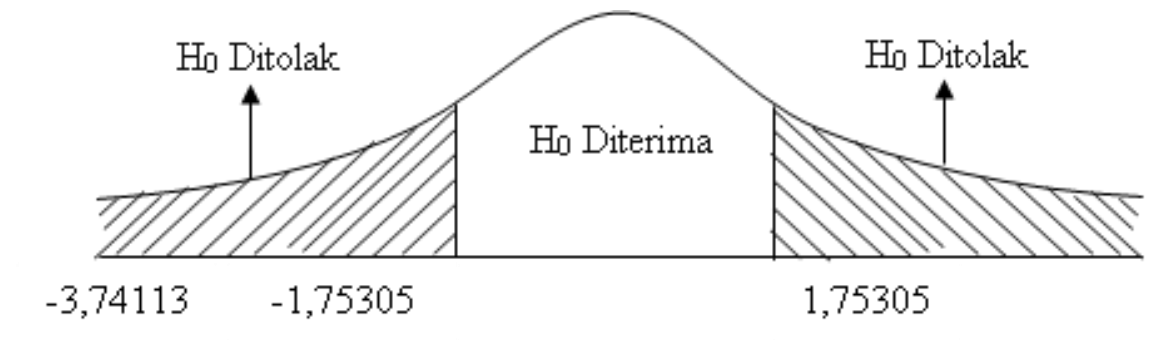

Hasil dari Hiptesis Pertumbuhan Ekonomi (X3) t hitung nilainya adalah 5,16085, dimana nilai t tabel pada $\mathrm{df}=\mathrm{n}-\mathrm{k}=18-3=15$ dan $\alpha=0,05$ yaitu 1,75305 . Sedangkan dilihat dari probabilitasnya, nilai probabilitas $t-$ statistik adalah sebesar 0,0004 dimana nilai tersebut lebih kecil daripada derajad kesalahan $\alpha=0,05$. Berdasarkan hasil pengujian $t$ hitung, $t$ tabel dan probabilitas maka diputuskan untuk menolak $\mathrm{H} 0$, dan menerima $\mathrm{H} 1$, dan dapat dijelaskan bahwa variabel pertumbuhan ekonomi berpengaruh posittif dan signifikan terhadap utang luar negeri.

Gambar 3. Kurva daerah penerimaan dan penolakan HO untuk Variabel Pertumbuhan Ekonomi (X3) pada Uji t Dua Arah

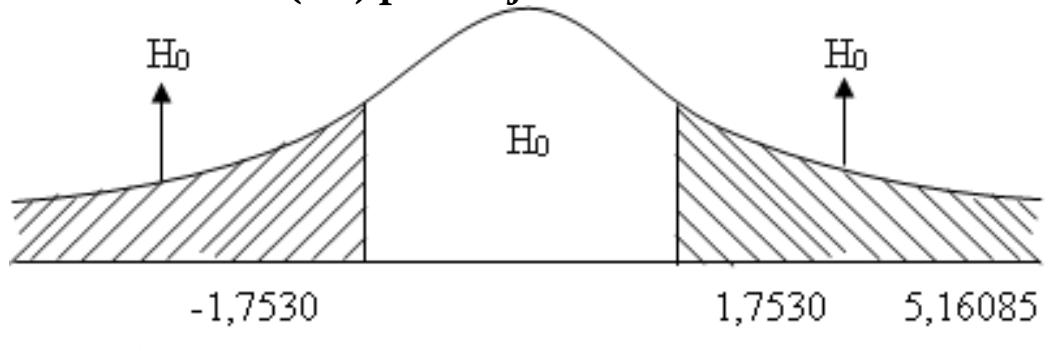

Koefisien Determinasi (R2)

Hasil pengujian dengan menggunakan regresi linier berganda (OLS) menghasilkan nilai adjusted R2 sebesar 0,9379 (93,79\%) yang berarti bahwa sebanyak 93,79\% dari variasi atau perubahan - perubahan utang luar negeridi Indonesia dapat dijelaskan oleh variasi dari variabel indepanden yang ada, sedangkan $6,21 \%$ dijelaskan sebab yang lain diluar model yang ada dalam penelitian ini.

Berdasarkan hasil dari pengujian t-statistik menggunakan metode OLS dapat diketahui sebagai berikut :

Tabel 1. Hasil Pengujian t-Statistik

\begin{tabular}{lllll}
\hline Variabel & Koefisien & Probabilitas & Sig & Keterangan \\
\hline X1 & 1,85 & 0,0001 & 0,05 & $\begin{array}{l}\text { Signifikan } \\
(5 \%)\end{array}$ \\
X2 & $-0,12$ & 0,0038 & 0,05 & $\begin{array}{l}\text { Signifikan } \\
(5 \%)\end{array}$ \\
X3 & 1,05 & 0,0004 & 0,05 & $\begin{array}{l}\text { Signifikan } \\
(5 \%)\end{array}$ \\
\hline
\end{tabular}

Sumber : Data diolah, 2018

Sehingga secara keseluruhan model dapat ditulis sebagai berikut :

$$
\mathrm{Y}=-3,090+1,85 \mathrm{X} 1-0,12 \mathrm{X} 2+1,05 \mathrm{X} 3
$$

Dari persamaan diatas dapat dijelaskan bahwa konstanta sebesar $-3,09$ menunjukkan tidak ada variabel independen (nilai $=0$ ), maka Utang Luar Negeri akan tetap ada sebesar -3,09, koefisien regresi Nilai Tukar Rupiah (X1) 
adalah 1,85 positif yang mengindikasikan jika Nilai tukar rupiah naik sebesar $1 \%$ maka utang luar negeri akan naik sebesar 1,85\%. Untuk Inflasi (X2) adalah $-0,12$ negatif yang mengindikasikan jika Inflasi turun sebesar $1 \%$ maka Utang Luar Negeri akan naik sebesar 0,12\%. Untuk Pertumbuhan Ekonomi (X3) adalah 1,05 positif yang mengindikasikan jika Pertumbuhan Ekonomi naik sebesar 1\% maka Utang Luar Negeri akan naik sebesar 1,05\%.

1. Pengaruh nilai tukar rupiah terhadap utang luar negeri

Variabel nilai tukar rupiah memiliki nilai koefesien sebesar 1,85 , thitung sebesar 6,66 dengan nilai signifikan yang lebih kecil dari 0,05 yang menunjukan bahwa variabel nilai tukar rupiah memiliki pengaruh positif dan signifikan terhadap utang luar negeri. Hasil penilitian sejalan yang dilakukan oleh Tafonao (2016) yang menjelaskan bahwa terdapat pengaruh yang positif dan nilai tukar terhadap utang luar negeri.

Nilai kurs sangat mempengaruhi kondisi perekonomian berbagai variabel makro maupun mikro ekonomi. Bila ada fluktuasi nilai tukar setiap tahunnya maka negara tersebut akan mengalami pengaruh dan dampaknya. salah satunya utang luar negeri yang merupakan sumber dana pembangunan. Jika terjadi gejolak terdepresiasi nilai tukar rupiah yang mana negara melakukan pinjaman luar negeri tersebut, akan menyebabkan penambahan utang luar negeri, karena didalam itu nilai pinjaman dihitung dengan valuta asing, Sedangkan memiliki pinjaman luar negeri tersebut, akan menyebabkan menambah beban utang luar negeri, karena pembayaran cicilan pokok dan bunga pinjaman dihitung dengan mata uang negara peminjam tersebut. sehingga apabila nilai tukar rupiah apresiasi terhadap mata uang dollar amerika, maka pengurangan pinjaman akan selalu dikuti dengan kurs nilai mata uang tersebut begitupun sebaliknya apabila nilai tukar rupiah depresiasi terhadap mata uang dollar Amerika, maka penambahan pinjaman akan selalu diikuti dengan kurs nilai mata uang tersebut. Dari hasil penilitian terlihat positf, nilai tukar rupiah terhadap utang luar negeri yang artinya niai tukar rupiah relatif mengalami kenaikan terhadap dollar maka utang luar negeri akan mengikuti.

2. Pengaruh inflasi terhadap utang luar negeri

Variabel inflasi memiliki nilai koefesien sebesar -0,12, t-hitung sebesar -3,74 dengan nilai signifikan yang lebih kecil dari 0,05 yang menunjukan bahwa variabel inflasi memiliki pengaruh negatif dan signifikan terhadap utang luar negeri. Namun, hasil penilitian tidak sejalan yang dilakukan oleh Ristuningsih (2016) yang menjelaskan bahwa terdapat pengaruh yang positif dan inflasi terhadap utang luar negeri.

Dalam menganalisa hubungan tingkat inflasi terhadap utang luar negeri, dapat digunakan teori imported inflation. Dimana saat Indonesia mengalami inflasi, maka nilai tukar rupiah terhadap dollar akan lemah. Indonesia masih tergantung produk dari luar baik bahan baku atau bahan setengah jadi disektor barang dan jasa. Sehingga saat terjadi inflasi Indonesia, pemerintah membutuhkan dana yang lebih untuk memenuhi kebutuhan dalam negeri tersebut dan dibutuhkanlah utang luar negeri. Dari hasil pengujian diatas mana angka inflasi menurun walaupun 
fluktuaif tetapi utang luar negeri juga semakin naik sehingga hasilnya negatif, artinya Inflasi tidak dapat mengurangi beban utang luar negeri yang semakin bertambah setiap tahunnya.

3. Pengaruh pertumbuhan ekonomi terhadap utang luar negeri

Variabel pertumbuhan ekonomi memiliki nilai koefesien sebesar 1,05, t-hitung sebesar 5,16 dengan nilai signifikan yang lebih kecil dari 0,05 menunjukan bahwa variabel pertumbuhan ekonomi signifikan dan memiliki pengaruh positif terhadap utang luar negeri. Namun hasil penilitian yang dilakukan oleh Tafonao (2016) yang menjelaskan bahwa terdapat pertumbuhan ekonomi tidak berpengaruh pengaruh terhadap total utang luar negeri.

Mempercepat pembangunan diperlukan investasi yang besar dan dana yang besar pula. Apabila dana dalam negeri tidak mencukupi, biasanya negara melakukan pilihan dengan meminjam ke luar negeri untuk menghindari pembebanan warga negara. Negara berkembang sering kali didapati keadaan dimana pertumbuhan ekonomi jauh lebih rendah dari pada potensi pertumbuhan yang sebenarnya dapat dicapai. Di negara-negara berkembang, konsep Produk Domestik Bruto (PDB) adalah konsep yang lebih bagus dipakai dari pada konsep pendapatan nasional lainnya. Produk domestik bruto sebagai nilai barang-barang dan jasa-jasa yang diproduksikan atau dihasilkan oleh suatu negara dalam jangka waktu tertentu (Sukirno, 2000:63), Sehingga dari pendapatan nasioanal bisa mengurangi utang luar. Tetapi dari hasil penilitian diatas terlihat pertumbuhan ekonomi yang stagnan walaupun dalam tren kenaikan tetapi utang luar negeri juga semakin naik sehingga hasilnya positif, artinya pertumbuhan ekonomi yang stagnan tidak dapat mengurangi beban utang luar negeri yang semakin bertambah setiap tahunnya

\section{KESIMPULAN}

Berdasarkan hasil pengujian hipotesis dan pembahasan didapati hasil sebagai berikut :

Nilai tukar rupiah berpengaruh signifikan dan memiliki hubungan pesitif dengan nilai koefisien sebesar 1,38 dan tingkat signifikansi pada tingkat $5 \%$ terhadap utang luar negeri di Indonesia. Bila nilai tukar rupiah terhadap dollar meningkat maka utang luar negeri akan meningkat. Inflasi berpengaruh signifikan dan memiliki hubungan negatif dengan nilai koefisien sebesar -0,12 dan signifikan pada tingkat 5\% terhadap utang luar negeri di Indonesia. Bila inflasi menurun maka utang luar negeri akan meningkat dan Pertumbuhan ekonomi berpengaruh signifikan dan memiliki hubungan yang positif dengan nilai koefisien sebesar 1,05 dan signifikan pada tingkat 5\% terhadap utang luar negeri di Indonesia. Bila pertumbuhan ekonomi meningkat maka utang luar negeri akan meningkat. Sedangkan yang memiliki pengaruh paling besar terhadap utang luar negeri yaitu nilai tukar rupiah dengan nilai koefisien sebesar 1,38 dan signifikan pada tingkat 5\% dan memiliki hubungan yang negatif terhadap utang luar negeri. Bila nilai tukar rupiah terhadap dollar meningkat maka utang luar negeri di Indonesia meningkat. 


\section{SARAN}

Adapun saran yang dapat di berikan oleh peneliti berdasarkan hasil penelitian yang telah dilakukan, sebagai berikut : Pemerintah harus tetap mengambil kebijakan yang optimal untuk menjaga, dan mengawasi aga nilai tukar tetap stabil agar tidak memperbesar utang luar negeri, Pemerintah harus tetap menjaga dan mengawasi agar inflasi tetap terjaga sehingga tidak berdampak memperbesar utang luar negeri, Pemerintah dan lembaga terkait terus mempercepat laju pertumbuhan ekonomi yang tinggi dan berkualitas untuk mendapatkan pendapatan nasional yang cukup agar berdampak dapat mengurangi beban utang luar. DanSebaiknya pemerintah harus menurunkan jumlah utang luar negeri dengan menstabilkan nilai tukar rupiah terhadap dollar agar menghindari beban utang dan cicilan bunga yang ditanggung lebih besar dan terjadinya krisis ekonomi di masa yang akan datang.

\section{DAFTAR PUSTAKA}

Atmaja, Adwin Surya. 2000. "Utang Luar Negeri Pemerintah Indonesia: Perkembangan dan Dampaknya". Jurnal Akuntansi dan Keuangan.

Astanti, Ayu. 2015. "Analisis Kausalitas Antara Utang Luar Negeri dan Pertumbuhan Ekonomi di Indonesia Tahun 1990-2013". Skripsi Ilmu Ekonomi dan Studi Pembangunan. Fakultas Ekonomi Universitas Jember : Jember

Boediono. 1990, Ekonomi Makro: Pengantar Ilmu Ekonomi. Jogjakarta: BPFE Yogyakarta

Gujarati, Damodar N, Down C. Porter. 2012. Dasar-dasar Ekonometrika Edisi 5. Jakarta Selatan: Salemba Empat.

Kuncoro, Mudrajad. 2013, Metode Riset Untuk Bisnis dan Ekonomi Bagaimana Meneliti dan Menulis Tesis?; Edisi keempat. Jakarta: Erlangga.

Machmud, Amir. 2016. Perekonomian Indonesia: Pacca Reformasi. Jakarta. Erlangga.

Madura, Jeff. 2002. Manajemen Keuangan Internasional, Edisi kesatu. Jakarta: Erlangga. Ciracas.

Mankiw, N Gregory. 2012. Pengantar Ekonomi Makro. Jakarta Selatan: Salemba Empat.

Tafanoa, Niati. 2016. "Analisis Faktor-Faktor Yang Mempengaruhi Utang Luar Negeri Indonsia Tahun 1996-2014”. Jurnal ekonomi.

Ristuningsi, Septiyanti. 2016. "Analisis Faktor-faktor yang mempengaruhi Utang Luar Negeri Tahun 1984-2014”. Jurnal ekonomi.

Ramadhani, Muhammad Adib. 2014."Pengaruh Defisit Anggaran, pengeluaran Pemerintah dan Hutang Luar Terhadap Pertumbuhan Ekonomi (Studi Kasus 6 Negara Asean Tahun 2003-2012”. E-Jurnal Ilmu Ekonomi Universitas Brawijaya.

Samuelson, Paul A dan William, D Nordhaus 2004. Ilmu Makroekonomi; Edisi Bahasa Indonesia. Jakarta: PT Media Global Edukasi. 
Simorangkir, Iskandar Suseno. 2004. Sistem Dan Kebijakan Nilai Tukar, Seri Kebangsentralan No.12. Jakarta: Penerbit Pusat Pendidikan dan Kebangsentralan Bank Indonesia.

Sukirno, Sadono. 2010. Makro Ekonomi: Teori Pengantar; Edisi ketiga. Jakarta: Raja Grafindo Persada

Supriyanto., Sampurna, Agung F. 1999. Utang Luar Negeri Indonesia: Argumen Relevansi dan Implikasinya Bagi Pembangunan. Jakarta: Karya Unipress.

Suryana. 2000. Ekonomi Pembangunan: Problematika dan Pendekatan. Jakarta: Selemba Empat. 